\title{
Effective Strategies for Global Health Training Programs A Systematic Review of Training Outcomes in Low and Middle Income Countries
}

\author{
Aprill Z. Dawson ${ }^{1}$, Rebekah J. Walker ${ }^{1,2}$, Jennifer A. Campbell ${ }^{1} \&$ Leonard E. Egede ${ }^{1,2,3}$ \\ ${ }^{1}$ Center for Health Disparities Research, Medical University of South Carolina, 135 Rutledge Avenue, \\ Charleston, SC, USA \\ ${ }^{2}$ Health Equity and Rural Outreach Innovation Center (HEROIC), Charleston VA HSR\&D COIN, Ralph H. \\ Johnson VAMC, 109 Bee Street, Charleston, SC, USA \\ ${ }^{3}$ Division of General Internal Medicine and Geriatrics, Department of Medicine, Medical University of South \\ Carolina, 135 Rutledge Avenue, Charleston, SC, USA \\ Correspondence: Leonard E. Egede, MD, MS, Medical University of South Carolina, Center for Health \\ Disparities Research, 135 Rutledge Avenue, Room 280, Charleston, SC 29425, USA. Tel: 1-843-792-2969; Fax: \\ 1-843-876-1201. E-mail: egedel@musc.edu
}

Received: January 23, 2016 Accepted: February 24, 2016 Online Published: March 31, 2016

doi:10.5539/gjhs.v8n11p278 URL: http://dx.doi.org/10.5539/gjhs.v8n11p278

\begin{abstract}
Introduction: Low and middle-income countries face a continued burden of chronic illness and non-communicable diseases while continuing to show very low health worker utilization. With limited numbers of medical schools and a workforce shortage the poor health outcomes seen in many low and middle income countries are compounded by a lack of within country medical training.
\end{abstract}

Methods: Using a systematic approach, this paper reviews the existing literature on training outcomes in low and middle-income countries in order to identify effective strategies for implementation in the developing world. This review examined training provided by high-income countries to low- and middle-income countries.

Results: Based on article eligibility, 24 articles were found to meet criteria. Training methods found include workshops, e-learning modules, hands-on skills training, group discussion, video sessions, and role-plays. Of the studies with statistically significant results training times varied from one day to three years. Studies using both face-to-face and video found statistically significant results.

Discussion: Based on the results of this review, health professionals from high-income countries should be encouraged to travel to low- middle-income countries to assist with providing training to health providers in those countries.

Keywords: global health, training outcomes, workforce training, effective strategies

\section{Introduction}

Non-communicable diseases (NCDs) caused about 35 million deaths in $2005,80 \%$ of which occurred in lowand middle-income countries (World Health Organization, 2010). Many of these non-communicable diseases are chronic illnesses, which have negative effects on the quality of life of individuals, and often lead to premature death (World Health Organization, 2005). Chronic diseases reduce life expectancy and economic productivity. This reduction in life expectancy leads to a decrease in workforce and in turn may result in lower gross domestic product (GDP) and gross national income (GNI) (Abegunde, 2006). Low- and middle-income countries are facing a growing burden of chronic illness and NCDs, in addition to an ongoing need to address traditional communicable diseases (World Health Organization, 2009). Africa has $24 \%$ of the world's global burden of disease but only $3 \%$ of the world's health workers, utilizing less than $1 \%$ of world health expenditures (World Health Organization, 2006). Often, countries with the lowest need have the highest numbers of health workers and countries with the greatest burden of disease are equipped with a much smaller health workforce (World Health Organization, 2006). The global shortage of healthcare workers is approximately 4.3 million with the greatest shortage in South East Asia and in sub-Saharan Africa (World Health Organization, 2006). In addition, 
there are only 168 medical schools in sub-Saharan Africa, eleven countries do not have a medical school, and 24 countries only have one medical school (Mullan et al., 2011).

Beyond a workforce shortage, one of the most common barriers faced by healthcare providers of developing countries is inadequate training and skills (Knight et al., 2013). Objectives of training are to increase knowledge, improve attitudes, strengthen skills, and improve work behavior (Holland et al., 2012). A review by Knight et al. illustrates the need for proper training and dissemination of guidelines to health care workers in developing countries (Knight et al., 2013). Without these things healthcare workers are treating patients with antiquated methods and recommendations (Knight et al., 2013). For example, in Latin America there was frequent improper use of magnesium sulphate in capacities that did not align with best-practice guidelines (Aaserud et al., 2005). With quality training, healthcare workers can effectively work to improve the health of citizens in their country. Healthcare workers who perform at their best are able to produce health services at a level and rate that matches their training and ability. Therefore, as the quality of training improves the potential quality of health-service delivery also improves (Scheffler et al., 2012).

Analysis of training outcome data is not generally practiced in many countries (Reij et al., 2013). Some countries have begun implementation of innovative medical education, however few outcomes have been recorded (Celletti et al., 2011). Outcomes of training data can provide information on the effectiveness of the training provided, performance of individuals who have been trained, and appropriate dissemination of training programs can be determined (Reij et al., 2013). Given the limited resources in low- and middle-income countries, outcomes of training data can also offer insight into resource prioritization and best practices to ensure the highest quality training is available given resource availability (Mullan et al., 2011).

This review focused on training provided by high-income countries to low- and middle-income countries. Through a systematic review of the available literature, this study aimed to review the existing literature on training outcomes in low and middle income countries in order to identify effective strategies for implementation in the developing world and provide recommendations to researchers and healthcare workers on strategies to employ when providing training in developing countries.

\section{Methods}

A systematic approach was taken to identify peer-reviewed articles on training provided by high-income countries to low- and middle-income countries. Medline was searched on 2 October 2014 for articles published in English between 2000 and 2014. Medline was selected as the most widely available public database, and therefore the most likely to be accessed by researchers, physicians, and trainers. The search terms were determined based on keywords found in papers by Cho et al. (2013) and van Lonkhuijzen et al. (2010). Some of the keywords found in the articles were not used due to the goals of this paper. For example Cho et al suggested using "advisor", "mentor", "mentee", and "support" in addition to the words we selected in Training Group 2. We omitted these words because we wanted to focus on training of medical doctors and not provision of training through mentorship or support programs. All authors reviewed the possible keywords, and agreed on the final keywords prior to searching. The search terms and strategy is provided in Table 1.

Table 1. Search strategy

\begin{tabular}{ll}
\hline Search Term & Key Words \\
\hline Global Health & global health, international health \\
Low Resource Country & low income, middle income, developing country, low resource \\
Training (Group 1) & train, education, staff development, patient simulation, in-service training \\
Training (Group 2) & supervise, teach, train, coach
\end{tabular}

Note. Papers used: any in 'global health' category and any in 'low resource country' category and any in 'training (group 1)' and any in 'training (group 2)' category.

A total of 9897 papers were retrieved and imported into EndNote software. After removing duplicates 9889 titles were reviewed. Eligibility criteria included: 1) published in English, 2) published between the years 2000 and 2014 , 3) training interventions, studies in low- or middle- income countries, 4) adult patient population. Interventions used for care, studies conducted in high-income countries, and systematic reviews were excluded. Title review excluded 8725 articles for reasons such as written prior to the year 2000, not peer-reviewed, studied children, or were not in English. The remaining 1164 were reviewed by abstract and 1106 were excluded. 
Articles were excluded for reasons such as did not provide outcome data, or conducted in high income countries. Fifty-eight full text outcome articles were assessed for final eligibility. Thirty-four were excluded for the following reasons: 11 - no training was provided, 9 - training was provided by citizens of the low-resource country, 3 - pilot studies, 3 - no outcome data or statistical analysis, 1 - trained nurses, 1 - works in progress, 1 - developed country, 2 - lab training, 1 - study was conducted across multiple countries, 1 - protocol, 1 - article was retracted.

For purposes of this review we operationalized major terms as: training outcomes - outcomes as chosen by the study under review for the outcome of their training program (ie. skills, knowledge); chronic illness - diseases that are not passed from person to person and that last a long time or progress slowly (World Health Organization, 2016); effective strategies - training that produced statistically significant changes in identified outcomes; low- and middle- outcome countries - countries with a gross national income per capita for the previous year of $\$ 12,736$ or less (The World Bank, 2015).

Data were collected from each manuscript including the country where the training was provided, trainers' country of origin, training length of time, specialty, study type and the outcome that was measured. Data were also collected regarding training outcomes, including pre-training levels, post-training levels, and the statistical significance. Due to the systematic nature of the search, the results were structured to provide more comprehensive information than a narrative review. However, due to the heterogeneity of the results, including study design, sample size, and training outcomes selected by authors, we did not conduct a meta-analysis upon conclusion of the review. As very few studies used a randomized controlled design, and a large amount of heterogeneity existed in the amount of information provided on details surrounding the training program, we chose to provide the information in the results rather than measuring study rigor.

\section{Results}

\subsection{Study Selection and Data Collection}

Articles were reviewed for eligibility in a systematic fashion. After duplicates were removed, 9889 articles remained for review. Fifty-eight articles were assessed for final eligibility and fully reviewed. Thirty-four additional papers were excluded from the final synthesis, resulting in twenty-four eligible studies identified based on the pre-determined eligibility criteria.

Data collected from the eligible articles are shown in Tables 2 and 3. The number of study participants ranged from 12 to 12,795, training duration ranged from one day to three years. There were also a variety of study designs used for the papers reviewed including: 12 pre-post-test, 5 quasi-experimental, 1 randomized control trial, 3 cluster randomized control trials, 1 prospective comparison, and 2 cross-sectional designs. Due to the heterogeneity of the studies reviewed we did not conduct an assessment of the risk of bias.

Table 2. Characteristics of studies meeting eligibility criteria

\begin{tabular}{|c|c|c|c|c|c|c|c|c|}
\hline $\begin{array}{l}\text { Study } \\
\text { Author, } \\
\text { Year }\end{array}$ & $\begin{array}{l}\text { Country where } \\
\text { training was } \\
\text { provided }\end{array}$ & $\begin{array}{l}\text { Trainer } \\
\text { country of } \\
\text { origin }\end{array}$ & $\begin{array}{l}\text { Participants } \\
\text { (Completed) }\end{array}$ & Specialty & $\begin{array}{l}\text { Training } \\
\text { duration }\end{array}$ & Training setting & Study design & Outcome measured \\
\hline $\begin{array}{l}\text { Ajuwon, } \\
2008\end{array}$ & Nigeria & $\begin{array}{l}\text { Not } \\
\text { Specified }\end{array}$ & $133(97)$ & Research Ethics & $\begin{array}{l}3 \text { rounds of } \\
3 \text { days, } 7 \\
\text { hours/day }\end{array}$ & $\begin{array}{l}\text { Workshops, } \\
\text { group sessions }\end{array}$ & Pre-Post Test & Knowledge \\
\hline $\begin{array}{l}\text { Arreola-Ri } \\
\text { sa, } 2007\end{array}$ & Mexico & $\begin{array}{l}\text { Not } \\
\text { Specified }\end{array}$ & $\begin{array}{l}3726 \text { trauma } \\
\text { patients }\end{array}$ & $\begin{array}{l}\text { Emergency } \\
\text { Medical } \\
\text { Services (EMS) }\end{array}$ & $\begin{array}{l}3-11 \\
\text { months, 2-3 } \\
\text { hours/day }\end{array}$ & Classes & $\begin{array}{l}\text { Quasi-experime } \\
\text { ntal }\end{array}$ & Mortality rate \\
\hline $\begin{array}{l}\text { Autry, } \\
2013\end{array}$ & Uganda & $\begin{array}{l}\text { United } \\
\text { States }\end{array}$ & $18(15)$ & $\begin{array}{l}\text { Obstetrics and } \\
\text { Gynecology }\end{array}$ & 4 weeks & $\begin{array}{l}\text { Remote, video } \\
\text { teaching }\end{array}$ & $\begin{array}{l}\text { Randomized } \\
\text { Control Trial, } \\
\text { Pre-Post Test }\end{array}$ & $\begin{array}{l}\text { Two-handed knot } \\
\text { tying }\end{array}$ \\
\hline Baig, 2008 & Malawi & $\begin{array}{l}\text { Scotland } \\
\text { and Norway }\end{array}$ & $\begin{array}{l}57 \text { Malawi } \\
\text { students, } 71 \\
\text { Univ. of } \\
\text { Edinburgh } \\
\text { students }\end{array}$ & Psychiatry & 2 weeks & Classes & $\begin{array}{l}\text { Quasi-experime } \\
\text { ntal }\end{array}$ & $\begin{array}{l}\text { Student exam } \\
\text { performance }\end{array}$ \\
\hline
\end{tabular}




\begin{tabular}{|c|c|c|c|c|c|c|c|c|}
\hline $\begin{array}{l}\text { Bedada, } \\
2015\end{array}$ & Botswana & Canada & 12 & Surgery & 3 days & Workshops & $\begin{array}{l}\text { Quasi-experime } \\
\text { ntal }\end{array}$ & $\begin{array}{l}\text { Patient safety and } \\
\text { sustainability of } \\
\text { MAS program }\end{array}$ \\
\hline $\begin{array}{l}\text { Brown, } \\
2000\end{array}$ & Honduras & $\begin{array}{l}\text { Not } \\
\text { Specified }\end{array}$ & $87(79)$ & $\begin{array}{l}\text { Ambulatory } \\
\text { Care }\end{array}$ & $\begin{array}{l}3 \frac{1 / 2 \text { day }}{} \\
\text { sessions }\end{array}$ & Workshops & Pre-Post Test & $\begin{array}{l}\text { Interpersonal } \\
\text { communication, } \\
\text { patient satisfaction }\end{array}$ \\
\hline $\begin{array}{l}\text { Dizon, } \\
2014\end{array}$ & Philippines & $\begin{array}{l}\text { Not } \\
\text { Specified }\end{array}$ & 31 & $\begin{array}{l}\text { Variety of health } \\
\text { professionals }\end{array}$ & 1 day & $\begin{array}{l}\text { Lectures, } \\
\text { practice } \\
\text { sessions, and } \\
\text { small group } \\
\text { discussion }\end{array}$ & Pre-Post Test & $\begin{array}{l}\text { Knowledge and } \\
\text { skills in } \\
\text { Evidence-Based } \\
\text { Practice }\end{array}$ \\
\hline $\begin{array}{l}\text { Dodani, } \\
2008\end{array}$ & Pakistan & $\begin{array}{l}\text { United } \\
\text { States }\end{array}$ & $80(56)$ & $\begin{array}{l}\text { Healthcare } \\
\text { Physicians }\end{array}$ & 9 days & $\begin{array}{l}\text { Face-to-face and } \\
\text { video-teleconfer } \\
\text { encing }\end{array}$ & $\begin{array}{l}\text { Quasi-experime } \\
\text { ntal, Pre-Post } \\
\text { Test }\end{array}$ & $\begin{array}{l}\text { Short- and } \\
\text { long-term } \\
\text { effectiveness of } \\
\text { research training }\end{array}$ \\
\hline $\begin{array}{l}\text { Goodwin, } \\
2012\end{array}$ & India & $\begin{array}{l}\text { Not } \\
\text { Specified }\end{array}$ & $160(143)$ & $\begin{array}{l}\text { Paramedic } \\
\text { students }\end{array}$ & 2 days & Classes & $\begin{array}{l}\text { Prospective } \\
\text { comparison }\end{array}$ & $\begin{array}{l}\text { ACLS cognitive } \\
\text { exam scores }\end{array}$ \\
\hline $\begin{array}{l}\text { Goudar, } \\
2012\end{array}$ & India & $\begin{array}{l}\text { United } \\
\text { States }\end{array}$ & 12795 babies & $\begin{array}{l}\text { Physicians, } \\
\text { Nurse } \\
\text { Mid-wives, } \\
\text { TBAs }\end{array}$ & $1,3,5$ days & $\begin{array}{l}\text { Trainer of } \\
\text { trainers } \\
\text { Didactic and } \\
\text { practice sessions }\end{array}$ & $\begin{array}{l}\text { Cluster } \\
\text { Randomized } \\
\text { Control Trial }\end{array}$ & $\begin{array}{l}\text { Perinatal and } \\
\text { neonatal mortality }\end{array}$ \\
\hline $\begin{array}{l}\text { Hashmi, } \\
2013\end{array}$ & Pakistan & $\begin{array}{l}\text { Not } \\
\text { Specified }\end{array}$ & 1227 & $\begin{array}{l}\text { Anesthesiology, } \\
\text { Emergency } \\
\text { Medicine, } \\
\text { Surgical } \\
\text { subspecialties }\end{array}$ & 2 days & $\begin{array}{l}\text { Classes } \\
\text { (modified } \\
\text { current } \\
\text { curriculum) }\end{array}$ & Pre-Post Test & $\begin{array}{l}\text { In-hospital } \\
\text { complication and } \\
\text { mortality }\end{array}$ \\
\hline $\begin{array}{l}\text { Hoban, } \\
2013\end{array}$ & Ethiopia & $\begin{array}{l}\text { United } \\
\text { States and } \\
\text { Europe }\end{array}$ & $111(69)$ & $\begin{array}{l}\text { Health } \\
\text { Educators }\end{array}$ & 2 days & $\begin{array}{l}\text { Lecture and } \\
\text { skills practice }\end{array}$ & Pre-Post Test & $\begin{array}{l}\text { Resuscitation } \\
\text { knowledge }\end{array}$ \\
\hline
\end{tabular}

\begin{tabular}{|c|c|c|c|c|c|c|c|c|}
\hline & & & & Village & & & & \\
\hline $\begin{array}{l}\text { Husum, } \\
2003\end{array}$ & $\begin{array}{l}\text { Cambodia and } \\
\text { Iraq }\end{array}$ & Norway & $44(42)$ & $\begin{array}{l}\text { healthcare } \\
\text { workers }\end{array}$ & 3 years & Classes & Pre-Post Test & $\begin{array}{l}\text { Health effects and } \\
\text { sustainability }\end{array}$ \\
\hline
\end{tabular}

\begin{tabular}{|c|c|c|c|c|c|c|c|c|}
\hline $\begin{array}{l}\text { Husum, } \\
2003\end{array}$ & $\begin{array}{l}\text { Cambodia and } \\
\text { Iraq }\end{array}$ & Norway & 44 & Paramedics & 3 years & Classes & Pre-Post Test & $\begin{array}{l}\text { Pre-hospital } \\
\text { physiologic } \\
\text { severity levels, } \\
\text { trauma mortality, } \\
\text { infectious } \\
\text { complications }\end{array}$ \\
\hline
\end{tabular}

\begin{tabular}{|c|c|c|c|c|c|c|c|c|}
\hline $\begin{array}{l}\text { Kauye, } \\
2014\end{array}$ & Malawi & $\begin{array}{l}\text { United } \\
\text { Kingdom }\end{array}$ & 22 & $\begin{array}{l}\text { Primary } \\
\text { healthcare } \\
\text { workers }\end{array}$ & 3,5 days & $\begin{array}{l}\text { Training } \\
\text { sessions }\end{array}$ & $\begin{array}{l}\text { allocation with } \\
\text { repeated } \\
\text { cross-sectional } \\
\text { surveys }\end{array}$ & $\begin{array}{l}\text { Diagnosis and } \\
\text { management of } \\
\text { cases }\end{array}$ \\
\hline $\begin{array}{l}\text { Kebede, } \\
2012\end{array}$ & Ethiopia & $\begin{array}{l}\text { United } \\
\text { States }\end{array}$ & 24 hospitals & Hospital CEOs & $\begin{array}{l}3-3 \text { week } \\
\text { blocks over } \\
2 \text { years }\end{array}$ & MHA program & Pre-Post Test & $\begin{array}{l}\text { Adherence } \\
\text { management } \\
\text { standards }\end{array}$ \\
\hline $\begin{array}{l}\text { Kulier, } \\
2012\end{array}$ & $\begin{array}{l}\text { Argentina, } \\
\text { Brazil, Dem. } \\
\text { Rep. of Congo, } \\
\text { India, } \\
\text { Philippines, S. }\end{array}$ & $\begin{array}{l}\text { Not } \\
\text { Specified }\end{array}$ & $\begin{array}{l}60 \text { clinical } \\
\text { training units } \\
(46)\end{array}$ & $\begin{array}{l}\text { Obstetrics and } \\
\text { gynecology }\end{array}$ & 8 weeks & $\begin{array}{l}\text { e-learning } \\
\text { self-directed } \\
\text { course }\end{array}$ & $\begin{array}{l}\text { International } \\
\text { cluster } \\
\text { randomized } \\
\text { control trial }\end{array}$ & $\begin{array}{l}\text { Knowledge, skills, } \\
\text { educational } \\
\text { environment }\end{array}$ \\
\hline
\end{tabular}


Africa,

Thailand

\begin{tabular}{|c|c|c|c|c|c|c|c|c|}
\hline $\begin{array}{l}\text { Levine, } \\
2011\end{array}$ & $\begin{array}{l}\text { Uganda, El } \\
\text { Salvador }\end{array}$ & $\begin{array}{l}\text { United } \\
\text { States }\end{array}$ & $\begin{array}{l}45 \text { (42 initial } \\
\text { posttest, } 18 \text { at } 6 \\
\text { month } \\
\text { follow-up) }\end{array}$ & $\begin{array}{l}\text { Healthcare } \\
\text { providers }\end{array}$ & 5 days & $\begin{array}{l}\text { Lectures and } \\
\text { practice }\end{array}$ & Pre-Post Test & $\begin{array}{l}\text { Knowledge and } \\
\text { comfort level }\end{array}$ \\
\hline $\begin{array}{l}\text { Lewin, } \\
2005\end{array}$ & S. Africa & $\begin{array}{l}\text { Not } \\
\text { Specified }\end{array}$ & 24 clinics & $\begin{array}{l}\text { Primary care } \\
\text { clinic staff }\end{array}$ & 6 weeks & $\begin{array}{l}\text { Experiential } \\
\text { learning } \\
\text { sessions }\end{array}$ & $\begin{array}{l}\text { Cluster } \\
\text { randomized } \\
\text { control trial }\end{array}$ & $\begin{array}{l}\text { Patient adherence, } \\
\text { treatment } \\
\text { outcomes }\end{array}$ \\
\hline $\begin{array}{l}\text { Makaniuol } \\
\text { a, } 2012\end{array}$ & Nigeria & $\begin{array}{l}\text { Not } \\
\text { Specified }\end{array}$ & 24 & $\begin{array}{l}\text { Teachers who } \\
\text { train primary } \\
\text { care providers }\end{array}$ & 5 days & Workshop & Pre-Post Test & $\begin{array}{l}\text { Knowledge, } \\
\text { beliefs, and } \\
\text { attitudes }\end{array}$ \\
\hline $\begin{array}{l}\text { Tomatis, } \\
2011\end{array}$ & Peru & $\begin{array}{l}\text { Not } \\
\text { Specified }\end{array}$ & 220 & $\begin{array}{l}\text { Physicians in } \\
\text { training, } \\
\text { practicing } \\
\text { physicians, } \\
\text { allied health } \\
\text { professionals }\end{array}$ & 3 days & $\begin{array}{l}\text { Lectures and } \\
\text { workshops }\end{array}$ & Pre-Post Test & $\begin{array}{l}\text { Competence and } \\
\text { importance to } \\
\text { practice }\end{array}$ \\
\hline $\begin{array}{l}\text { vanHeng, } \\
2008\end{array}$ & Cambodia & Europe & 21 & $\begin{array}{l}\text { Assistant } \\
\text { medical } \\
\text { officers, trauma } \\
\text { care providers }\end{array}$ & 3 weeks & Classes & Pre-Post Test & $\begin{array}{l}\text { Self-confidence, } \\
\text { surgical skill, } \\
\text { teamwork }\end{array}$ \\
\hline $\begin{array}{l}\text { Wang, } \\
2014\end{array}$ & $\begin{array}{l}\text { Ghana and } \\
\text { Liberia }\end{array}$ & $\begin{array}{l}\text { United } \\
\text { States }\end{array}$ & 15 & Medical doctors & 2 days & $\begin{array}{l}\text { Didactic } \\
\text { lectures, hands } \\
\text { on practice, } \\
\text { discussion } \\
\text { sessions }\end{array}$ & $\begin{array}{l}\text { Quasi-experime } \\
\text { ntal }\end{array}$ & Surgical capacity \\
\hline Wee, 2011 & Singapore & $\begin{array}{l}\text { Not } \\
\text { Specified }\end{array}$ & 658 & $\begin{array}{l}\text { Medical } \\
\text { students }\end{array}$ & $\begin{array}{l}1 / 2 \text { academic } \\
\text { year }\end{array}$ & $\begin{array}{l}\text { Comparison of } \\
\text { students who } \\
\text { participated in } \\
\text { PHS, NHS, or } \\
\text { both. }\end{array}$ & Cross-sectional & $\begin{array}{l}\text { Leadership, } \\
\text { communication, } \\
\text { teamwork, critical } \\
\text { thinking skills }\end{array}$ \\
\hline
\end{tabular}

Table 3. Summary of intervention and outcomes for studies meeting eligibility criteria

\begin{tabular}{|c|c|c|c|}
\hline Author, Year & Intervention Description & Outcome Measured & Statistical Significance \\
\hline $\begin{array}{l}\text { Ajuwon, } \\
2008\end{array}$ & $\begin{array}{l}\text { Three sets of training workshops lasting } 21 \text { hours over } 3 \\
\text { days. Workshops were facilitated by } 7 \text { individuals with } \\
\text { previous training and experience in research ethics. } \\
\text { Techniques included: lecture, Q\&A, group discussion of } \\
\text { case studies. Information covered included: research } \\
\text { ethics, principles of research ethics, ethics in research } \\
\text { design, ethical issues in drug trials, confidentiality, } \\
\text { informed consent, conflicts of interest, and scientific } \\
\text { misconduct. }\end{array}$ & Knowledge & $\begin{array}{l}\text { Knowledge of principles of } \\
\text { research ethics increased from } \\
0.67 \text { to } 2.25 \text { out of } 3(\mathrm{p}<0.05) \\
\text { Application of research ethics } \\
\text { increased from } 2.64 \text { to } 3.05 \\
\text { ( } \mathrm{p}<0.05) \\
\text { Knowledge about IRB operations } \\
\text { increased from } 6.05 \text { to } 6.29 \text { out of } \\
7(\mathrm{p}<0.05)\end{array}$ \\
\hline $\begin{array}{l}\text { Arreola-Risa, } \\
2007\end{array}$ & $\begin{array}{l}\text { Green Cross }-3 \text { month programs provided by the Green } \\
\text { Cross } \\
\text { Red Cross }-11 \text { month programs provided by the Red } \\
\text { Cross. Taught pre-hospital care skills like rescue and } \\
\text { extrication } \\
\text { In both programs students went to classes for } 2-3 \text { hours } \\
\text { per day }\end{array}$ & Mortality Rate & $\begin{array}{l}\text { Mortality - decreased from } 6.3 \% \\
\text { to } 2.5 \%(p<0.001)\end{array}$ \\
\hline
\end{tabular}


Autry, 2013 Three faculty members at the University of California, 2-handed knot tying San Francisco led the video teaching sessions for 1hour. 3:1 student to faculty ratio. A Ugandan faculty member facilitated the teaching sessions only by offering technical support and keeping track of the time. Each intern had 3 different teaching sessions with different faculty

Baig, 2008 Two weeks of theoretical teaching to students in Malawi. Exam in Malawi comparable Edinburgh students received theoretical teaching spread to that given in Scotland over 5 months in the $3^{\text {rd }}$ year.

Bedada, 2015 A minimal access surgery training program was developed Patient safety, technical in 2006 that was composed of knowledge and skills independence and training. An initial 3-day workshop was carried out in sustainability of the minimal 2006. Emphasis was placed on teaching at psychomotor access surgery (MAS) and cognitive levels. This was a training of the trainers program workshop. Trainers then went on to train junior level colleagues

Brown, 2000 Nine local trainers participated in a 2-day Communication practices by training-of-trainers and helped deliver the intervention. trained and untrained Interpersonal Communication (IPC) training was providers conducted in $3-1 / 2$ day sessions with a maximum of 20 participants. The course focused on communication methods and skills were grouped into: overall socio-emotional communication, problem-solving skills, and counseling.
Score improvement of $50 \%$ or more in 6 out of 8 in the intervention group compared with 1 out of 7 in the control group $(\mathrm{p}=0.04)$

There was no significant difference between the scores on the exams taken by the Malawi students and the Scotland students

Shorter length of stay in laparoscopic group $(\mathrm{p}<0.001)$

Increased proportion of laparoscopic cases completed without the presence of expatriate surgeons $(\mathrm{p}=0.001)$

Trained providers communicated more $(\mathrm{p}=0.001)$

Trained providers had more positive talk $(\mathrm{p}=0.001)$

Criticism and negative talk was less common in trained providers $(\mathrm{p}=0.018)$

Trained providers used 3 times more emotional talk $(\mathrm{p}=0.021)$

Trained providers were more likely to ask the patient if they understood instructions $(\mathrm{p}=0.025)$

Medical counseling was more frequent in trained providers $(\mathrm{p}=0.026)$

Improvements in provider communication resulted in an increase in patient communication, and provision of more medical information

Trained providers received higher patient satisfaction ratings

Knowledge and skills in EBP significantly improved from preto post-training in both groups $(\mathrm{P}<0.05$ in both groups $)$

The workshop was found to be effective in both groups (post-test $1, \mathrm{p}<0.0001) .36 \%$ increase in knowledge in the F2F group, and $24 \%$ increase in the VTC group.

Goodwin, Students from India were enrolled in a 2 year paramedic ACLS cognitive examination

Overall there was no significant difference in test score between accredited paramedic training programs in the US and 
were certified in the ACLS course within the prior 3 months. students.

The international ACLS course is effective in an international setting.

Goudar, 2012 The study was conducted in 26 clusters of Karnataka, Perinatal and neonatal India. A trainer of trainers model was developed and mortality experienced trainers trained a lead investigator and 2 site coordinators as national trainers. The national trainers were assisted by 2 more trainers and 1 or more cluster coordinator (CC) per community. Each of the training courses were 1-5 days held at different times. The CC's trained all active birth attendants in each community. Training of the $\mathrm{CC}$ was for 5 days, the Auxiliary Nurse Midwives and Traditional Birth Attendants for 3 days, and physicians for 1 day. After ENC data collection, clusters were randomized to NRP training or control.

Hashmi, Trauma quality improvement program components that Occurrence of in-hospital 2013 were implemented include: development of a complication and mortality multidisciplinary trauma team centered around a surgeon, mandatory 2 day training in western style trauma care, and a trauma outcomes feedback program was established.

Hoban, 2013 Trainings were held in 7 Ethiopian cities. The individuals Resuscitation knowledge who were trained were going to serve as trainers for others. Two day training of lecture and skill practice.

Husum, Training program consisted of three 150-hours courses Health effects and 2003a with working periods in between. A teaching manual in sustainability local languages was developed along with large posters with step-by-step instructions. Locally available animals were used for advanced life support training. These trained individuals then provided first responder training with a 2-day basic first aid training followed by a 1 day rehearsal training after 6 months.

Husum, Training program consisted of three 150-hours courses Effect of treatment on 2003b with working periods in between. A teaching manual in pre-hospital physiologic local languages was developed along with large posters severity levels, trauma with step-by-step instructions. Locally available animals mortality, infectious were used for advanced life support training. These trained complications individuals then provided first responder training with a 2-day basic first aid training followed by a 1 day rehearsal training after 6 months.

Kauye, 2014 The intervention was composed of a 5 day training Diagnosis and management program in mental health using a 5 unit tool-kit divided of cases into 30 minute sections. Each section consisted of lecture, group discussion and role-plays. The control group participants received 3 days of training using an existing lecture based syllabus.

Kebede, 2012 The training received was from a Masters of Healthcare Adherence to management and Hospital Administration degree program. standards

Kulier, 2012 The intervention group received elearning of Knowledge, skills, Evidence-Based Medicine (EBM) principles consisting of educational environment 5 recorded video sessions, and face-to-face teaching and learning with a clinical trainer. The control group participated in a self-directed learning course consisting of PowerPoint slides that were available online with the same learning objectives and content as the elearning materials; they also had a facilitator. The control and intervention
There was a significant increase in the proportion of infants who received bag and mask ventilation in the post ENC period.

There was a significant decrease in perinatal mortality rate in the post ENC period (RR 0.69, 95\% CI 0.53,0.90).

Skin-to-skin contact significantly increased in the NRP group $(\mathrm{p}=0.004)$

Unadjusted patient mortality decreased from $9.6 \%$ to $4.9 \%$ $(\mathrm{p}<0.05) ; \quad$ Unadjusted complication rate decreased from $13.5 \%$ to $9.8 \%(\mathrm{p}<0.05)$.

Significant improvement in resuscitation knowledge mean score improvement from $8.7 / 10$ to 9.4/10 ( $\mathrm{p}=0.003)$

Study reported significant reduction in overall mortality rate from $40 \%$ to $15.7 \%$

The mortality rate decreased from $40 \%$ to $14.9 \%$. Significant reduction in fatalities for injured torso from $61.5 \%$ to $19.1 \%$

32 times greater odds of diagnosing patients with depression in the intervention group

Percent of management standards met increased from $27 \%$ to $51 \%$ $(\mathrm{p}<0.001)$

After education there were significant increases in overall knowledge in the intervention group (38.1 vs 43.1; adjusted mean difference $4.9, \mathrm{p}<0.001)$ and in skills measured ( 8.3 vs 9.1 ; adjusted mean difference 0.7 , $\mathrm{p}=0.02$ ) 
activities were given in addition to the local teaching programs.

Levine, 2011 Training was provided by 2 visiting Ob/Gyn's over a 5 Knowledge and comfort day series of lectures and interactive training. Participants level observed screening upon completion of each lecture; and then performed the screening while being monitored

Lewin, 2005 Primary care clinic staff met with trainers for one 3-hour Patient adherence, treatment session weekly for 6 weeks. The training encouraged outcomes participants to think about their past experiences caring for patients with TB. Training was provided by two experienced nurse practitioners, and training was conducted in the preferred language of the staff

Makanjuola, One week training structured into 5 units: core concepts, Knowledge, beliefs, and 2012 core skills, common neurological disorders, WHO primary attitudes guidelines for mental health, health and policy issues. Each unit was divided into 30-minute modules delivered over 5 days. Modules consist of theory, discussion and role play

Tomatis, Researchers conducted 5 EBM courses over 5 years. One Competence and importance 2011 course was made up of 3 consecutive days of lectures and to practice workshops on basic principles of EBM. There were 2 or 3 45-minute interactive lectures each day. Each lecture was followed by a 45 -minute interactive workshop consisting of 3 parts: discussion of a case scenario, critical appraisal of a published study, guided discussion

Van Heng, Training was provided during 5 consecutive 150 hour 5 consecutive 150 hour 2008 courses and followed the "Village University" model. This courses based on 4 model consists of 4 concepts: 1) confidence, 2) principles: confidence, troubleshooting, 3) Learning by doing, and 4) This is a troubleshooting, learn by university. Live injured animals that were under anesthesia doing, this is a university. were used for training surgical techniques.

Trained using local animals

Wang, 2014 A team of 2 attending general surgeons and 1 Increase surgical capacity advanced-year general surgery resident from US academic institutions taught a 2-day course. The course consisted of didactic lectures, hands-on practice of mesh repair in the operating room, and discussion sessions. On average trainees participated in or observed a total of 6 six cases.

Wee, 2011 No training intervention was provided. This study Skills and application of compared the survey results of two different service knowledge learning programs at a medical school in Singapore.
Average score significantly increased from $62 \%$ to $81 \%$ $(\mathrm{p}<0.001)$; self-reported comfort levels of identifying abnormalities significantly increased form 2.1 to $3.3(\mathrm{p}<0.001)$

There were no statistically significant differences. However, the rate for successful treatment completion improved in the intervention clinic, and the cure rate improved by $2.5 \%$ in the intervention clinic and decreased by $7.9 \%$ in control clinic.

Overall knowledge of mental health issues increased from $60.4 \%$ to $73.7 \%(\mathrm{p}=0.001)$

Self-reported competence increased from 2 to $3(p<0.001)$

There were 4 deaths in the control group hospitals, and 2 in the intervention group. $22 \%$ had post-operative wound infections in the control group and $10.3 \%$ had infections in the intervention group

Mesh repairs had a significantly higher rate of orchitis compared to the non-mesh group $5.7 \%$ vs $1.3 \%(\mathrm{p}=0.03)$

For students who participated in both PHS and NHS the rating of the NHS was significantly higher $(\mathrm{p}=0.032)$

Studies were conducted in Argentina, Botswana, Brazil, Cambodia, Democratic Republic of Congo, El Salvador, Ethiopia, Ghana, Honduras, India, Iraq, Liberia, Malawi, Mexico, Nigeria, Pakistan, Peru, Philippines, Singapore, South Africa, Thailand, and Uganda. Trainers came from Canada, England, Norway, Scotland, United States, and other countries in Europe. Papers focused on specialties in anesthesiology, ambulatory care, Emergency Medical Services, health education, midwifery, obstetrics and gynecology, physicians, psychiatry, surgery, research ethics. Outcomes measured include: knowledge, mortality rate, skills such as 2-handed knot tying, interpersonal communication, short- and long-term effectiveness of research training, health effects and sustainability, diagnosis and management of cases, adherence to standards, educational environment, comfort level, patient adherence, treatment outcomes, beliefs and attitudes, errors, competence and importance to practice, self-confidence, surgical skill, teamwork, leadership skills, ability to identify social issues, gaining and 
application of knowledge.

\subsection{Study Characteristics and Results of Individual Studies}

Study characteristics and results of individual studies are shown in Tables 2 and 3. Sample sizes ranged from 12 to 12795. Samples included physicians/healthcare workers being trained and clusters of regions where trainings were conducted (Ajuwon et al., 2008; Arreola-Risa et al., 2007; Autry et al., 2013; Baig et al., 2008; Bedada et al., 2015; Brown et al., 2000; Dizon et al., 2014; Dodani et al., 2008; Goodwin et al., 2011; Goudar et al., 2011; Hashmi et al., 2013; Hoban et al., 2013; Husum et al., 2003a; Husum et al., 2003b; Kauye et al., 2014; Kebede et al., 2012; Kulier et al., 2012; Levine et al., 2011; Lewin et al., 2005; Makanjuola et al., 2012; Tomatis et al., 2011; van Heng et al., 2008; Wang et al., 2014; Wee etal., 2011). Intervention duration ranged from one day to three years. Twelve of the studies were pre-post- test design (Ajuwon et al., 2008; Brown et al., 2000; Dizon et al., 2014; Hashmi et al. 2013; Hoban et al., 2013; Husum et al., 2003a; Husum et al., 2003b; Kebede et al., 2012; Levine et al., 2005; Makanjuola et al., 2012; Tomatis et al., 2011; vanHeng et al., 2008), 5 were quasi-experimental design (Arreola-Risa et al., 2007; Baig et al., 2008; Bedada et al., 2015; Dodani et al., 2008; Wang et al., 2014), three were Cluster randomized control trials (Goudar et al., 2011; Kulier et al., 2012; Lewin et al., 2011). 2 were cross-sectional design (Kauye et al., 2014; Wee et al., 2011), 1 randomized control trial (Autry et al., 2013), and 1 prospective comparison study (Goodwin et al., 2011).

Of the 24 eligible studies, 1 conducted 1 day training, 13 conducted 2-30 day trainings, 3 conducted 1-3 month trainings, 1 conducted 3-6 month training, and 6 conducted trainings that lasted longer than 6 months, 1 did not report any training methods. Twenty-one of the studies had significant results, 2 studies had results that were not significant, and 1 study did not state whether the result were significant or not as reported in Table 4. One study with insignificant results indicate that there was no significant difference between similar methods of instructions used between two different populations of students indicating that the method can effectively be used amongst a variety of groups (Baig et al., 2008; Goodwin et al., 2011). The second study did not produce statistically significant results however being able to increase the rate of treatment completion and the cure rate of tuberculosis may be clinically significant (Lewin et al., 2011).

Out of the 24 articles, four measured knowledge (Ajuwon et al., 2008; Baig et al., 2008; Dodani et al., 2008; Goodwin et al., 2011), eight measured skill (Brown et al., 2000; Goudar et al., 2011; Hashmi et al., 2013; Husum et al., 2003a; Husum et al., 2003b; Kauye et al., 2014; Kebede et al., 2012; Lewin et al., 2005), seven measured knowledge and skill (Autry et al., 2013; Dizon et al., 2014; Hoban et al., 2013; Kulier et al., 2012; Levine et al., 2011; Wang et al., 2014; Wee et al., 2011), two measured mortality and skill (van Heng et al., 2008; Arreola-Risa et al., 2007), one measured knowledge and attitudes (Makanjuola et al., 2012), and two measured knowledge, skill, and attitudes (Kulier et al., 2012; Tomatis et al., 2011).

Table 4 provides a comparison of the training methods used in eligible studies. Training methods included workshops, e-learning modules, hands-on skills training, group discussion, video sessions, and role-plays. Of the studies with statistically significant results training times varied from one day to three years. Studies using both face-to-face and video found statistically significant results.

Table 4. Summary of significant training programs

\begin{tabular}{|c|c|c|c|c|c|c|c|c|c|c|c|c|c|}
\hline $\begin{array}{l}\text { Author, } \\
\text { Year }\end{array}$ & $\begin{array}{l}\text { Trainer } \\
\text { from } \\
\text { DC } \\
\text { Only }\end{array}$ & $\begin{array}{l}\text { Trainer } \\
\text { from } \\
\mathrm{HC} \text { and } \\
\mathrm{DC}\end{array}$ & $\begin{array}{l}\text { Trainin } \\
\text { g } 1 \text { day }\end{array}$ & $\begin{array}{l}\text { Trainin } \\
\text { g } 2-30 \\
\text { days }\end{array}$ & $\begin{array}{l}\text { Trainin } \\
\mathrm{g} \\
1-3 \mathrm{~m}\end{array}$ & $\begin{array}{l}\text { Trainin } \\
\mathrm{g} \\
3-6 \mathrm{~m}\end{array}$ & $\begin{array}{l}\text { Training } \\
>6 \\
\text { months }\end{array}$ & $\begin{array}{l}\mathrm{T} \\
\mathrm{T}\end{array}$ & FFT & VT & ST & KT & SIM \\
\hline $\begin{array}{l}\text { Ajuwon, } \\
2008\end{array}$ & $*$ & $*$ & & $\mathrm{x}$ & & & & & $\mathrm{x}$ & & & $\mathrm{x}$ & $\mathrm{x}$ \\
\hline $\begin{array}{l}\text { Arreola-Ri } \\
\text { sa, } 2007\end{array}$ & & $\mathrm{x}$ & & & & $\mathrm{x}$ & $\mathrm{x}$ & & $\mathrm{x}$ & & $\mathrm{x}$ & & $\mathrm{x}$ \\
\hline $\begin{array}{l}\text { Autry, } \\
2013\end{array}$ & $\mathrm{x}$ & & & & $\mathrm{X}$ & & & & & $\mathrm{x}$ & $\mathrm{x}$ & & $\mathrm{x}$ \\
\hline
\end{tabular}




\begin{tabular}{|c|c|c|c|c|c|c|c|c|c|c|c|c|c|}
\hline $\begin{array}{l}\text { Author, } \\
\text { Year }\end{array}$ & $\begin{array}{l}\text { Trainer } \\
\text { from } \\
\text { DC } \\
\text { Only }\end{array}$ & $\begin{array}{l}\text { Trainer } \\
\text { from } \\
\mathrm{HC} \text { and } \\
\mathrm{DC}\end{array}$ & $\begin{array}{l}\text { Trainin } \\
\text { g } 1 \text { day }\end{array}$ & $\begin{array}{l}\text { Trainin } \\
\text { g } 2-30 \\
\text { days }\end{array}$ & $\begin{array}{l}\text { Trainin } \\
\mathrm{g} \\
1-3 \mathrm{~m}\end{array}$ & $\begin{array}{l}\text { Trainin } \\
\mathrm{g} \\
3-6 \mathrm{~m}\end{array}$ & $\begin{array}{l}\text { Training } \\
>6 \\
\text { months }\end{array}$ & $\begin{array}{l}\mathrm{T} \\
\mathrm{T}\end{array}$ & FFT & VT & ST & KT & SIM \\
\hline Baig, 2008 & $\mathrm{x}$ & & & $\mathrm{x}$ & & & & & $\mathrm{x}$ & & & $\mathrm{x}$ & \\
\hline $\begin{array}{l}\text { Bedada, } \\
2015\end{array}$ & & $\mathrm{x}$ & & $\mathrm{X}$ & & & & $\mathrm{x}$ & $\mathrm{x}$ & & $\mathrm{x}$ & $\mathrm{x}$ & $x$ \\
\hline $\begin{array}{l}\text { Brown, } \\
2000\end{array}$ & & $\mathrm{x}$ & & $\mathrm{X}$ & & & & $\mathrm{x}$ & $\mathrm{x}$ & & $\mathrm{X}$ & $\mathrm{x}$ & $\mathrm{x}$ \\
\hline $\begin{array}{l}\text { Dizon, } \\
2014\end{array}$ & & $\mathrm{x}$ & $\mathrm{X}$ & & & & & & $\mathrm{x}$ & & & & $x$ \\
\hline $\begin{array}{l}\text { Dodani, } \\
2008\end{array}$ & $\mathrm{X}$ & & & $\mathrm{X}$ & & & & & $\mathrm{x}$ & $\mathrm{X}$ & & $\mathrm{x}$ & $\mathrm{x}$ \\
\hline $\begin{array}{l}\text { Goodwin, } \\
2011\end{array}$ & $*$ & $*$ & & & & & $\mathrm{x}$ & & $\mathrm{x}$ & & & $\mathrm{x}$ & \\
\hline $\begin{array}{l}\text { Goudar, } \\
2011\end{array}$ & & $\mathrm{x}$ & & $\mathrm{X}$ & & & & $\mathrm{x}$ & $\mathrm{x}$ & & $\mathrm{x}$ & $\mathrm{x}$ & \\
\hline $\begin{array}{l}\text { Hashmi, } \\
2013\end{array}$ & * & * & & $\mathrm{x}$ & & & & & $\mathrm{x}$ & & $\mathrm{X}$ & $\mathrm{x}$ & $x$ \\
\hline $\begin{array}{l}\text { Hoban, } \\
2013\end{array}$ & & $\mathrm{X}$ & & $\mathrm{x}$ & & & & $\mathrm{x}$ & $\mathrm{x}$ & & & $\mathrm{x}$ & $\mathrm{x}$ \\
\hline $\begin{array}{l}\text { Husum, } \\
2003\end{array}$ & & $\mathrm{x}$ & & & & & $\mathrm{x}$ & & $\mathrm{x}$ & & $\mathrm{x}$ & $\mathrm{x}$ & $\mathrm{x}$ \\
\hline $\begin{array}{l}\text { Husum, } \\
2003\end{array}$ & & $\mathrm{x}$ & & & & & $\mathrm{x}$ & & $\mathrm{x}$ & & $\mathrm{x}$ & $\mathrm{x}$ & $\mathrm{x}$ \\
\hline $\begin{array}{l}\text { Kauye, } \\
2014\end{array}$ & & $\mathrm{x}$ & & $\mathrm{x}$ & & & & & $\mathrm{x}$ & & & $\mathrm{x}$ & $\mathrm{x}$ \\
\hline $\begin{array}{l}\text { Kebede, } \\
2012\end{array}$ & & $\mathrm{x}$ & & & & & $\mathrm{x}$ & & $\mathrm{x}$ & & $\mathrm{x}$ & $\mathrm{x}$ & $\mathrm{x}$ \\
\hline $\begin{array}{l}\text { Kulier, } \\
2012\end{array}$ & & $\mathrm{x}$ & & & & & & & $\mathrm{x}$ & $\mathrm{x}$ & $\mathrm{x}$ & $\mathrm{x}$ & $\mathrm{x}$ \\
\hline $\begin{array}{l}\text { Levine, } \\
2011\end{array}$ & $\mathrm{x}$ & & & $\mathrm{x}$ & & & & & $\mathrm{x}$ & & $\mathrm{x}$ & $\mathrm{x}$ & $\mathrm{x}$ \\
\hline $\begin{array}{l}\text { Lewin, } \\
2005\end{array}$ & & $\mathrm{x}$ & & & $\mathrm{x}$ & & & & $\mathrm{x}$ & & $\mathrm{X}$ & $\mathrm{x}$ & \\
\hline $\begin{array}{l}\text { Makanjuol } \\
\text { a, } 2012\end{array}$ & & $\mathrm{x}$ & & $\mathrm{x}$ & & & & & $\mathrm{x}$ & & & $\mathrm{x}$ & $\mathrm{x}$ \\
\hline
\end{tabular}




\begin{tabular}{|c|c|c|c|c|c|c|c|c|c|c|c|c|c|}
\hline $\begin{array}{l}\text { Author, } \\
\text { Year }\end{array}$ & $\begin{array}{l}\text { Trainer } \\
\text { from } \\
\text { DC } \\
\text { Only }\end{array}$ & $\begin{array}{l}\text { Trainer } \\
\text { from } \\
\mathrm{HC} \text { and } \\
\mathrm{DC}\end{array}$ & $\begin{array}{l}\text { Trainin } \\
\text { g } 1 \text { day }\end{array}$ & $\begin{array}{l}\text { Trainin } \\
\text { g } 2-30 \\
\text { days }\end{array}$ & $\begin{array}{l}\text { Trainin } \\
\mathrm{g} \\
1-3 \mathrm{~m}\end{array}$ & $\begin{array}{l}\text { Trainin } \\
\text { g } \\
3-6 \mathrm{~m}\end{array}$ & $\begin{array}{l}\text { Training } \\
>6 \\
\text { months }\end{array}$ & $\begin{array}{l}\mathrm{T} \\
\mathrm{T}\end{array}$ & FFT & VT & ST & KT & SIM \\
\hline $\begin{array}{l}\text { Tomatis, } \\
2011\end{array}$ & & $\mathrm{x}$ & & $\mathrm{x}$ & & & & & $\mathrm{x}$ & & & $\mathrm{x}$ & $\mathrm{x}$ \\
\hline $\begin{array}{l}\text { van Heng, } \\
2008\end{array}$ & $\mathrm{x}$ & & & & $\mathrm{x}$ & & & & $\mathrm{x}$ & & $\mathrm{x}$ & $\mathrm{x}$ & $\mathrm{x}$ \\
\hline $\begin{array}{l}\text { Wang, } \\
2014\end{array}$ & $\mathrm{x}$ & & & $\mathrm{x}$ & & & & & $\mathrm{x}$ & & $\mathrm{x}$ & $\mathrm{x}$ & $\mathrm{x}$ \\
\hline Wee, 2011 & N/A & N/A & & & & & $\mathrm{x}$ & & & & & & $\mathrm{x}$ \\
\hline
\end{tabular}

x Study had that criteria, * Trainer country of origin was not specified, N/A Training was not provided.

$\mathrm{DC}=$ Developed Country, $\mathrm{HC}=$ Host Country, $\mathrm{TT}=$ Train the trainer, $\mathrm{FFT}=$ Face to Face training, VT=Video Training,

$\mathrm{ST}=$ Skills Training, KT=Knowledge Training, SIM=Significant improvement measured.

\section{Discussion}

The purpose of this paper was to review the existing literature on training outcomes in low and middle-income countries in order to identify effective strategies for implementation in the developing world. Based on the literature and small number of eligible studies for this review, few studies have examined the effectiveness of training and how to integrate information found in research into training practice or programs. Measuring quality has also proven to be a challenge due to the lack of a universal definition (World Health Organization, 2014). This review found that using a train-the-trainer model was effective in producing statistically significant improvements in the skill and knowledge of healthcare workers in low- and middle- income countries. In addition, studies with varied length of times were able to effectively train staff and result in positive changes in outcomes. Using both face-to-face and video or e-learning training was shown to be effective training methods. Additionally, based on the findings we recommend that both skill and knowledge training be provided simultaneously, if possible.

The finding that little has been published surrounding the effectiveness of training is supported by prior reviews of the literature. A review by Innvaer et al. found 24 studies that addressed decision makers using science based evidence to affect health policy decisions (2002). Only four of the studies included in the review were conducted in low- and middle- income countries, limiting the recommendations for developing countries (Innvaer et al., 2002). Due to the lack of evidence it is challenge to implement policy to address the training needs of low- and middle-income countries. This review, focused only on training completed in low- and middle-income countries, finding a similar lack of evidence. More needs to be done to ensure that research evidence is translated into practice and policy in developed and developing countries. Measuring the outcomes of training is important to ensure the most effective methods are disseminated and used.

Based on the papers that were reviewed in this study, a number of best practices should be considered by developing countries. Many studies report providing training by a trainer from a developed country along with a facilitator or moderator from the country where the training was being conducted. The relationships that are established in this manner may allow for more culturally appropriate delivery of the instructional material and enable those being trained to fully reap the benefits of the information being provided. A review by Pearce et al. found that 13 out of 18 studies noted that train-the-trainer programs were effective in disseminating knowledge and in improving patient outcomes (Pearce et al., 2012). Studies using a train-the-trainer model of training produced significant positive results in three studies in this review. This suggests that with effective train-the-trainer strategies low- and middle-income countries can continue to provide their healthcare staff with training in a sustainable manner. Fewer resources would be needed to train cohorts of trainers who in turn will be able to continue to provide training to incoming healthcare workers and refresher courses to veteran workers. Both face-to-face and video training were shown to be effective in the studies reviewed, increasing the options for offering training or follow-up sessions. 
The length of training did not seem to influence the significance of the results, with trainings as short as 1 day or up to 3 years showing statistical significance in improving outcomes in the healthcare system of lowmiddle-income countries. This indicates that cost-effective training can be provided through shorter courses and reduce strain on the health system by taking providers away from patients for extended periods of time. Long-term training is more likely to be used in academic institutions and is useful for very specialized subject areas. Short-term training can be done in community or academic environments. In order for short-term training to be effective the training should be provided in the native language, use training modules that allow for flexibility to meet the goals of the trainees, and sufficient follow-up of individuals who complete the training program (Holland et al., 2012). Many studies reviewed combined both knowledge and skills training, which is supported by theory and evidence to result in better outcomes (Yamnill et al., 2001). This is recommended for future training to ensure healthcare providers have the knowledge and skills necessary to change their practice.

\subsection{Limitations}

Though a systematic process was used to limit the likelihood of missing articles, some limitations exist. First, missing information was noted for some studies. For instance, some studies did not indicate the number of healthcare workers that were trained, only the number of facilities or communities that received the intervention. Other papers report numbers in terms of patients prior to training and post training (Hashmi et al., 2013), which may not be an effective measure if trained staff left the facility. Additional information would be beneficial to help determine the cost-effectiveness and true success or lack thereof of the interventions. Second, the search was limited to articles that were only published in English. Since the review is on low- and middle-income countries were frequently English is not the official or first language, studies with valuable information may have been excluded from this review. Third, studies with negative training outcomes may not have been published due to the results. Lastly, only 3 studies were randomized control trials. Other study designs may increase the risk of bias.

\subsection{Conclusions}

Based on the results of this review, health professionals from high-income countries should be encouraged to travel to low- middle-income countries to assist with providing training to health providers in those countries. The trainers traveling from developed countries should work with experienced healthcare providers within the country to ensure the provision of culturally appropriate training experience. Effective training programs with significant outcomes can be provided in one week or less; providing cost effective and time efficient training options for those with access to limited resources. Using both face-to-face and video or e-learning training was shown to be effective training methods. Additionally, based on the findings we recommend that both skill and knowledge training be provided simultaneously if possible. Finally, effort should be made to implement a train-the-trainer model of training to allow for a cost effective and sustainable method of training in low- and middle- income countries.

\section{Acknowledgements}

This work was supported by Grant K24DK093699-01 from The National Institute of Diabetes and Digestive and Kidney Disease (PI: Leonard Egede). The manuscript represents the views of the authors and not those of MUSC the VA or HSR\&D.

\section{Conflict of Interest}

The authors declare that there is no conflict of interests regarding the publication of this paper.

\section{References}

Aaserud, M., Lewin, S., Innvaer, S., Paulsen, E. J., Dahlgren, A. T., Trommald, M., ... Oxman, A. D. (2005). Translating research into policy and practice in developing countries: A case study of magnesium sulphate for pre-eclampsia. BMC Health Services Research, 5(68), 1-13.

Abegunde, D., \& Stanciole, A. (2006). An estimation of the economic impact of chronic non-communicable diseases in selected countries (Working Paper). Retrieved from World Health Organization website: http://www.who.int/chp/working_paper_growth\%20model29may.pdf?ua=1

Ajuwon, A. J., \& Kass, N. (2008). Outcome of a research ethics training workshop among clinicians and scientists in a Nigerian university. BMC Medical Ethics, 9(1), 1-9. http://dx.doi.org/10.1186/1472-6939-9-1

Arreola-Risa, C., Vargas, J., Contreras, I., \& Mock, C. (2007). Effect of emergency medical technician certification for all prehospital personnel in a Latin American city. TRAUMA, 63(4), 914-919. http://dx.doi.org/10.1097/ta.0b013e31806bf141 
Autry, A. M., Knight, S., Lester, F., Dubowitz, G., Byamugisha, J., Nsubuga, Y., ... Korn, A. (2013). Teaching surgical skills using video internet communication in a resource-limited setting. Obstetrics and Gynecology, 122(1), 127-131. http://dx.doi.org/10.1097/AOG.0b013e3182964b8c

Baig, B. J., Beaglehole, A., Stewart, R. C., Boeing, L., Blackwood, D. H., Leuvennink, J., \& Kauye, F. (2008). Assessment of an undergraduate psychiatry course in an African setting. BMC Medical Education, 8 (23), 1-6. http://dx.doi.org/10.1186/1472-6920-8-23

Bedada, A. G., Hsiao, M, Bakanisi, B., Motsumi, M., \& Azzie, G. (2015). Establishing a contextually appropriate laparoscopic program in resource-restricted environments. Annals of Surgery, 261(4), 807-811. http://dx.doi.org/10.1097/SLA.0000000000000691

Brown, L. D., De Negri, B., Hernandez, O., Dominguez, L., Sanchack, J. H., \& Roter, D. (2000). An evaluation of the impact of training Honduran health care providers in interpersonal communication. International Journal for Quality in Health Care, 12(6), 495-501. http://dx.doi.org/10.1093/intqhe/12.6.495

Celletti, F., Reynolds, T. A., Stoertz, A., \& Dayrit, M. (2011). Educating a new generation of doctors to improve the health of populations in low- and middle-income countries. PLoS Medicine, 8(10), 1-4. http://dx.doi.org/10.1371/journal.pmed.1001108

Cho, D-B., Cole, D., Simiyu, K., Luong, W., \& Neufeld, V. (2013). Mentoring, training and support to global health innovators: A scoping review. Global Journal of Health Science, 5(5), 162-173. http://dx.doi.org/10.5539/gjhs.v5n5p162

Dizon, J. M., Dizon, R. J., Regino, J., \& Gabriel, A. (2014). Evidence-based practice training for health professionals in the Philippines. Advances in Medical Education and Practice, 5, 89-94. http://dx.doi.org/10.2147/AMEP.S54459

Dodani, S., \& LaPorte, R. E. (2008). Ways to strengthen research capacity in developing countries: Effectiveness of a research training workshop in Pakistan. Journal of the Royal Institute of Public Health, 122, 578-587. http://dx.doi.org/10.1016/j.puhe.2007.09.003

Goodwin, T., Delasobera, B. E., Strehlow, M., Camacho, J., Koskovich, M., D’Souza, P., .. Mahadevan, S. V. (2011). Indian and United States paramedic students: Comparison of examination performance for the American Heart Association Advanced Cardiovascular Life Support (ACLS) training. The Journal of Emergency Medicine, 43(2), 298-302. http://dx.doi.org/10.1016/j.jemermed.2011.05.096

Goudar, S. S., Dhaded, S.M., McClure, E. M., Derman, R. J., Patil, V. D., Mahantshetti, N. S., ... Carlo, W. A. (2011). ENC training reduces perinatal mortality in Karnataka, India. The Journal of Maternal-Fetal and Neonatal Medicine, 25(6), 568-574. http://dx.doi.org/10.3109/14767058.2011.584088

Hashmi, Z. G., Haider, A. H., Zafar, S. N., Kisat, M., Moosa, A., Siddiqui, F., ... Zafar, H. (2013). Hospital-based trauma quality improvement initiatives: First step toward improving trauma outcomes in the developing world. Journal of Trauma and Acute Care Surgery, 75(1), 60-68. http://dx.doi.org/10.1097/TA.0b013e31829880a0

Hoban, R., Bucher, S., Neuman, I., Chen, M., Tesfaye, N., \& Spector, J. M. (2013). 'Helping Babies Breathe' training in Sub-Saharan Africa: Educational impact and learner impressions. Journal of Tropical Pediatrics, 59(3), 180-186. http://dx.doi.org/10.1093/tropej/fms077

Holland, R. (2012). Designing and implementing training programs. In M. Embrey, M. Ryan, \& L. Glassman (Eds.), Management Sciences for Health (52.1-52.20). Arlington, VA: Management Sciences for Health, Inc.

Husum, H., Gilbert, M., \& Wisborg, T. (2003). Training pre-hospital trauma care in low-income countries: The 'Village University' experience. Medical Teacher, 25(2), 142-148. http://dx.doi.org/10.1080/0142159031000092526

Husum, H., Gilbert, M., Wisborg, T., Van Heng, Y., \& Murad, M. (2003). Rural prehospital trauma systems improve trauma outcome in low-income countries: A prospective study from North Iraq and Cambodia. The Journal of TRAUMA Injury, Infection, and Critical Care, 54, 1188-1196. http://dx.doi.org/10.1080/0142159031000092526

Kauye, F., Jenkins, R., \& Rahman, A. (2014). Training primary health care workers in mental health and its impact on diagnoses of common mental disorders in primary care of a developing country, Malawi: A cluster-randomized controlled trial. Psychological Medicine, 44, 657-666. 
http://dx.doi.org/10.1017/S0033291713001141

Kebede, S., Mantopoulos, J., Ramanadhan, S., Cherlin, E., Gebeyehu, M., Lawson, R., \& Bradley, E. H. (2012). Educating leaders in hospital management: A pre-post study in Ethiopian hospitals. Global Public Health, 7(2), 164-174. http://dx.doi.org/10.1080/17441692.2010.542171

Knight, H. E., Self, A., \& Kennedy, S. H. (2013). Why are women dying when they reach hospital on time? A systematic review of the 'Third Delay'. PLoS ONE, 8, 1-9. http://dx.doi.org/10.1371/journal.pone.0063846

Kulier, R., Gülmezoglu, A. M., Zamora, J., Plana, M. N., Carroli, G., Cecatti, ... Khan, K. S. (2012). Effectiveness of a clinically integrated e-learning course in evidence-based medicine for reproductive health training. JAMA, 308(21), 2218-2225. http://dx.doi.org/10.1001/jama.2012.33640

Levine, L. D., Chudnoff, S. G., Taylor, K., Baganizi, M., \& Banks, E. (2011). A 5-day educational program for teaching cervical cancer screening using visual inspection with acetic acid in low-resource settings. International Journal of Gynecology and Obstetrics, 115, 171-174. http://dx.doi.org/10.1016/j.ijgo.2011.06.013.

Lewin, S., Dick, J., Zwarenstein, M., \& Lombard, C. J. (2005). Staff training and ambulatory tuberculosis treatment outcomes: A cluster randomized controlled trial in South Africa. Bulletin of the World Health Organization, 83(4), 250-259.

Makanjuola, V., Doku, V., Jenkins, R., \& Gureje, O. (2012). Impact of a one-week intensive 'training of trainers' workshop for community health workers in south-west Nigeria. Mental Health in Family Medicine, 9, 33-38.

Mullan, F., Frehywot, S., Omaswa, F., Buch E., Chen, C., Greysen, S. R., ... Neusy, A. (2011). Medical schools in sub-Saharan Africa. The Lancet, 377, 1113-1121. http://dx.doi.org/10.1016/S0140-6736(10)61961-7

Pearce, J., Mann, M. K., Jones, C., vanBuschbach, S., Olff, M., \& Bisson, J. I. (2012). The most effective way of delivering a train-the-trainers program: a systematic review. Journal of Continuing Education in the Helath Professions, 32(3), 215-226.

Reji, P., Aga, G., \& Abebe, G. (2013). The role of AFB microscopy training in improving the performance of laboratory professionals: analysis of pre and post training evaluation scores. BMC Health Services Research, 13, 1-7. http://dx.doi.org/10.1186/1472-6963-13-392

Scheffler, R. M., Bruckner, T., \& Spetz, J. (2012). The labour market for human resources for health in low- and middle-income countries. World Health Organization Human Resources for Health Observer, 11, 1-20.

The World Bank. (2015). http://data.worldbank.org/news/new-country-classifications-2015 Last Accessed: February 22, 2016.

Tomatis, C., Taramona, C., Rizo-Patrón, E., Hernández, F., Rodríguez, P., Piscoya, A., ... Estrada, C. A. (2011). Evidence-based medicine training in a resource-poor country, the importance of leveraging personal and institutional relationships. Journal of Evaluation in Clinical Practice, 17(4), 644-650. http://dx.doi.org/10.1111/j.1365-2753.2011.01635.x

van Heng, Y., Davoung, C., \& Husum, H. (2008). Non-doctors as trauma surgeons? A controlled study of trauma training for non-graduate surgeons in rural Cambodia. Prehospital and Disaster Medicine, 23(6), 483-489.

van Lonkhuijzen, L., Dijkman, A., van Roosmalen, J., Zeeman, G., \& Scherpbier, A. (2010). A systematic review of the effectiveness of training in emergency obstetric care in low-resource environments. BJOG, 117, 777-787. http://dx.doi.org/10.1111/j.1471-0528.2010.02561.x

Wang, Y. T., Mehes, M. M., Naseem, H. -R., Ibrahim, M., Butt, M. A., Ahmed, N., ... Abdullah, F. (2014). Assessing the impact of short-term surgical education on practice: A retrospective study of the introduction of mesh for inguinal hernia repair in sub-Saharan Africa. Hernia, 18, 549-556. http://dx.doi.org/10.1007/s10029-014-1255-3

Wee, L. E., Xin, Y. W., \& Koh, G. C-H. (2011). Doctors-to-be at the doorstep-comparing service-learning programs in an Asian medical school. Medical Teacher, 33, e471-e478. http://dx.doi.org/10.3109/0142159X.2011.588739

World Health Organization. (2005). Preventing chronic diseases a vital investment. Geneva, Switzerland: World Health Organization.

World Health Organization. (2006). Working together for health. Geneva, Switzerland: World Health 
Organization, 2006.

World Health Organization. (2009). Global health risks: mortality and burden of disease attributable to selected major risks. Geneva, Switzerland: World Health Organization.

World Health Organization. (2010). Package of Essential Noncommunicable (PEN) Disease Interventions for Primary Health Care in Low-Resource Settings. Geneva, Switzerland: World Health Organization.

World Health Organization. (2014). A universal truth: No health without a workforce. Geneva, Switzerland: World Health Organization.

World Health Organization. (2016). Noncommunicable diseases. Geneva, Switzerland: World Health Organization.

Yamnill, S., \& McLean, G. N. (2001). Theories of supporting transfer of training. Human Resource Development Quarterly, 12(2), 195-208.

\section{Copyrights}

Copyright for this article is retained by the author(s), with first publication rights granted to the journal.

This is an open-access article distributed under the terms and conditions of the Creative Commons Attribution license (http://creativecommons.org/licenses/by/3.0/). 